\title{
Keberlanjutan Peran Dukungan Sebaya di Dalam Sistem Penanggulangan HIV di Tingkat Provinsi dan Kota/Kabupaten Indonesia
}

\section{Sustainability of Peer Group Support in HIV/AIDS System in District and Provincial Level in Indonesia}

\author{
Sarah Handayani ${ }^{1}$, Retno Mardhiati ${ }^{1}$ \\ 1. Fakultas Ilmu-Ilmu Kesehatan Universitas Muhammadiyah Prof.Dr. HAMKA
}

(UHAMKA)

Email korespondensi: sarah_handayani@uhamka.ac.id

\begin{abstract}
Abstrak:
Latar Belakang. Peran Dukungan Sebaya (DS) adalah salah satu peran yang penting dalam Sistem Penaggulangan HIV/AIDS. DS dapat berjalan secara berkesinambungan jika ada faktor keberlanjutan program.

Tujuan. Penelitian ini bertujuan untuk mengetahui factor-faktor yang mempengaruhi keberlanjutan DS di dalam sistem penanggulangan HIV/AIDS di tingkat Provinsi dan Kota/Kabupaten.

Metode. Penelitian ini melakukan pengumpulan data kualitatif dan studi literatur. Wawancara mendalam dilakukan pada informan utama dan informan pendukung. Instrumen yang digunakan adalah pedoman wawancara mendalam.

Hasil. Kelompok DS dapat terus berlanjut dan berperan dalam sistem penanggulangan HIV/AIDS jika faktor-faktor yang berhubungan dengan keberlanjutan kelompok dapat terus berkembang. Adapun faktor keberlanjutan DS adalah: 1) Faktor Internal, yang meliputi faktor motivasi berkelompok, kepemimpinan, kemandirian dan manajemen serta akuntabilitas kelompok. 2) Faktor Eksternal, yang meliputi keterlibatan di dalam sistem penanggulangan HIV/AIDS, akses terhadap sumber daya dan masuk ke dalam sistem rujukan.
\end{abstract}

Kata Kunci: Kelompok Dukungan Sebaya, Keberlanjutan, HIV/AIDS, Indonesia

\begin{abstract}
Background: Role of peer group support is one of important role in HIV/AIDS prevention system. Peer group can be implemented contiiously if sustainability program factors exist.

Aim of Study:This study aimed to assess factors which effect peer group support sustainability in HIV/AIDS eradication both in district and provincial level.

Method: The study collected qualitative data and literature review. Indepth interview was conducted to key informants.

Result. Peer group support can be implemented in HIV/AIDS eradication system since factors that effect were developed. Those factors were 1) Internal factor includes group motivation, leadership, self help and group accountability. 2) External Factor includes participatory in HIV/AIDS eradication system, access to resources and referral system.
\end{abstract}

Keyword: peer group support, sustainability, HIV/AIDS, Indonesia 


\section{Pendahuluan}

Berawal dari Kelompok Dukungan Sebaya (KDS) yang pertama kali terbentuk di Indonesia pada tahun 1995, pola-pola dukungan KDS dimulai dengan pertemuan-pertemuan tertutup bagi ODHA untuk saling berbagi pengalaman, kekuatan dan harapan. Pola pun berkembang dengan kegiatan-kegiatan belajar bersama hingga keterlibatan ODHA lebih luas dalam penyebaran informasi dan advokasi terkait HIV. Semakin berkembang jumlah dan kegiatan KDS, kemudian berkembang koordinator di tingkat Provinsi, yang dinamakan Kelompok Penggagas (KP) (Riesman, 1965; Friedland, 2006; Green, 2007).

Strategi penanggulangan HIV dan AIDS ditujukan untuk mencegah dan mengurangi risiko penularan HIV, meningkatkan kualitas hidup ODHA, serta mengurangi dampak sosial dan ekonomi akibat HIV dan AIDS pada individu, keluarga dan masyarakat, agar setiap individu menjadi produktif dan bermanfaat untuk pembangunan (KPAN, 2010).

Keberlanjutan program secara nasional dapat dilihat dari perkembangan kelembagaan, peningkatan sumber daya manusia, dan peningkatan pendanaan (KPAN, 2010). Dalam sistem penanggulangan HIV/AIDS di tingkat provinsi dan kota atau kabupaten, keberlanjutan KP dan KDS dapat dilihat juga dari indikator tersebut (Spirita, 2001 dan Spiritia, 2006)

\section{Metodologi Penelitian}

Penelitian ini melakukan pengumpulan data kualitatif dan studi literatur. Wawancara mendalam dilakukan pada informan utama dan informan pendukung. Informan utama yaitu Koordinator KP dan KDS. Informan pendukung yaitu staf KPAP, staf KPAK, staf Dinas Kesehatan Provinsi. Jumlah informan adalah : 9 orang koordinator KP Provinsi, 21 koordinator
KDS, 10 orang staf KPAP dan 10 staf KPAK, dan 7 orang staf Dinas Kesehatan. Instrumen yang digunakan adalah pedoman wawancara mendalam. Adapun provinsi yang terpilih adalah: Sumatera Utara, DKI Jakarta, Jawa Barat, Jawa Timur, Nusa Tenggara Barat, Bali, Sulawesi Selatan, Kalimantan Barat, Nusa Tenggara Timur dan Papua.

Pengolahan data kualitatif meliputi tahapan transkrip rekaman wawancara, pemilahan data, serta pengkodean data dan informan. Jenis analisis data yang digunakan dalam penelitian kualitatif ini adalah analisis isi (content analysis) (Mc Dowell, 1987).

\section{Hasil}

\section{Peran Dukungan Sebaya}

Sejarah dukungan sebaya di Indonesia diawali oleh berkumpulnya 2 sampai 3 ODHA yang memiliki kesamaan dalam kejiwaan: senasib karena status HIV. Mereka saling membantu untuk memperkuat kepribadian yang lainnya. Sejalan dengan waktu pertemuan, beberapa ODHA yang memiliki kesamaan nasib melakukan pembentukan kelompok yang memiliki struktur organisasi sederhana. Kelompok ini bernama Kelompok Dukungan Sebaya (KDS).

Pengertian KDS adalah suatu kelompok yang terdiri dari dua atau lebih orang yang terinfeksi dan/atau terpengaruh langsung oleh HIV untuk berkumpul dan saling mendukung. Tujuan umum dari KDS adalah untuk mencapai mutu hidup yang lebih baik bagi ODHA dan OHIDHA. Pengertian KP adalah kelompok atau wadah dukungan sebaya yang berubah fungsi yaitu sebagai pengambil dan pelaksana inisiatif atau gagasan untuk mencapai mutu hidup ODHA dan OHIDHA yang lebih baik dengan melayani pembentukan, penguatan, dan pengembangan KDS dengan prinsip kesetaraan. KP melakukan aktifitas kegiatan di tingkat 
provinsi atau kabupaten atau kota. KP provinsi melakukan aktifitas di tingkat provinsi, dan menjadi inisiatif dalam pembentukan KP kabupaten dan kotamadya. Perkembangan kelompok sampai Mei 2011 telah terbentuk 18 $\mathrm{KP}$ provinsi, $8 \mathrm{KP}$ kabupaten atau kota di 21 provinsi.

Prosedur pembentukan KP dimulai berdasarkan inisiatif kelompok dukungan sebaya ketika jumlah anggota dan kebutuhan sudah tidak dapat dipenuhi secara menyeluruh oleh KDS. Pembentukan KP dilakukan dengan metode yang beragam. Ada yang merupakan inisiatif sebuah KDS, ada pula yang merupakan gabungan beberapa KDS atau individu. Tidak ada metode baku dalam hal ini. Semuanya disesuaikan dengan kebutuhan dan kesepakatan anggota.

Tabel 1. Matriks Variabel Keberlanjutan KP dan KDS

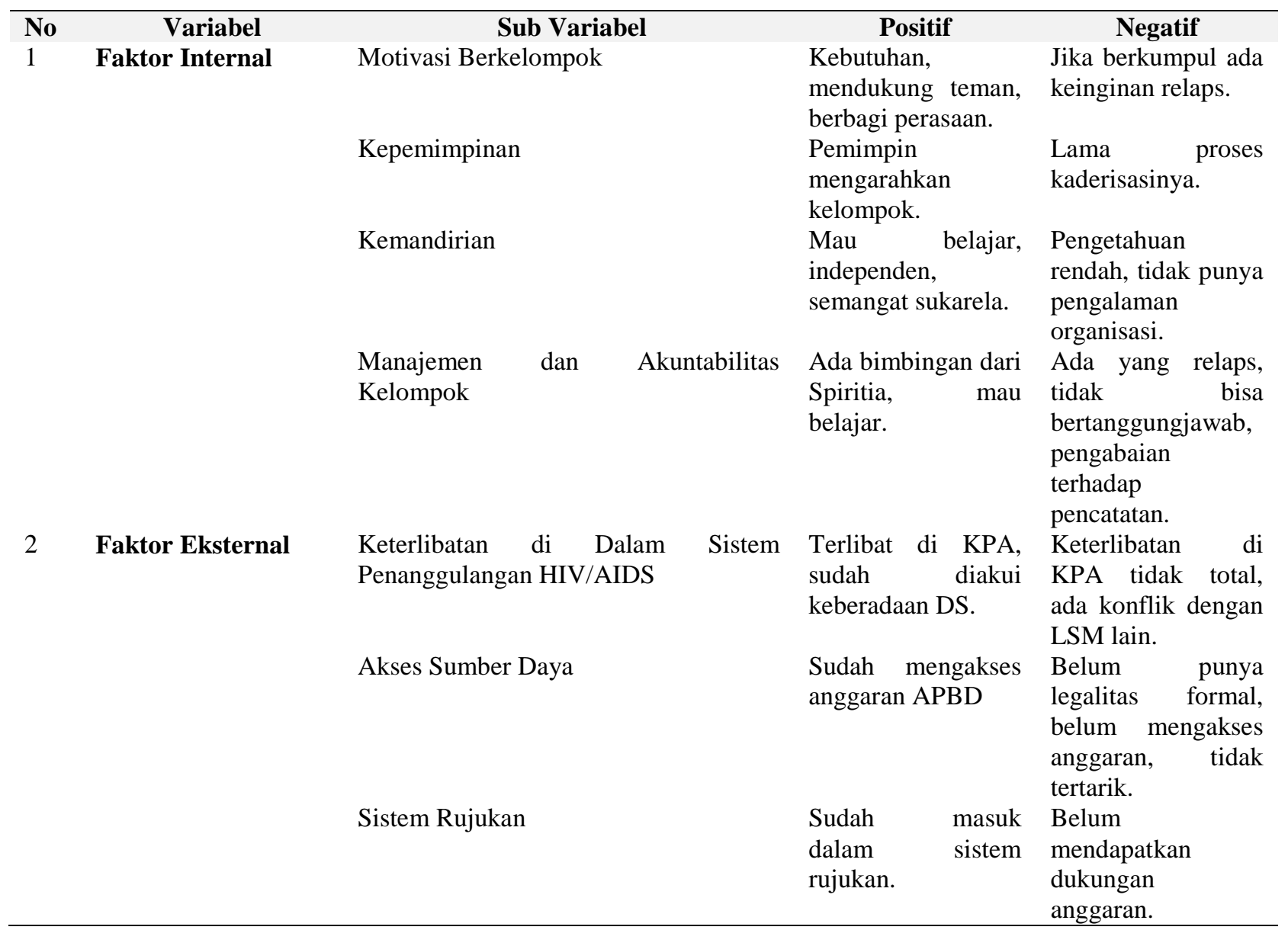




\section{Motivasi Berkelompok}

Pendiri KP dan KDS adalah ODHA, yang sejak awal memiliki kebutuhan kuat untuk berkumpul. Motivasi awal mereka membentuk kelompok, semuanya berdasarkan kebutuhan untuk berbagi. Baik berbagi perasaan, berbagi pengetahuan sampai berbagi cara untuk bisa mengatasi berbagai permasalahan yang mereka hadapi.

Berawal dari semangat untuk saling mendukung karena kebutuhan yang kuat untuk saling mendukung. Inisiatif seperti ini muncul karena sebagai orang yang juga terinfeksi mengalami masalah yang sama. Dorongan tersebut diantaranya tercermin dari ungkan Pendiri KP berikut ini.

"Semangat kami mendirikan karena melihat

kebutuhan, pertama dari teman-teman yang terinfeksi sendiri yang membutuhkan dukungan, pengetahuan, informasi, akses pengobatan karena masih banyak terjadi diskriminasi hubungan pertemanan dengan yang positif HIV..."

(Koordinator KP)

Kebutuhan untuk berkumpul diantaranya didorong oleh adanya berbagai permasalahan yang dialami oleh ODHA. Mulai dari beratnya menerima status, pengetahuan yang rendah dan berbagai permasalahan yang merupakan akibat dari kuatnya stigma di masyarakat. Motivasi ini sangat kuat dan mendorong ODHA untuk membentuk kelompok. Hal itu didukung oleh ungkapan berikut ini.

"Motivasi saya mendirikan Kelompok adalah untuk mensupport kepada teman yang IDU bahwa mereka tidak sendiri dan memiliki teman. Dengan temanteman kami menggagas untuk membangun isu-isu yang berkaitan dengan stigma. ."

(Koordinator KP)

Dorongan yang didukung atas dasar kebutuhan dan keinginan untuk memberikan dukungan tersebut kemudian menjadi motivasi yang kuat yang mempengaruhi kuatnya kepemimpinan di dalam kelompok. Selain didorong oleh kebutuhan yang kuat untuk saling mendukung, kebutuhan untuk bertukar pendapat dan perasaan juga merupakan dorongan yang besar dari setiap kelompok. Kebutuhan tersebut menjadi dorongan bagi kelompok untuk terus berkumpul karena ada berbagai masalah yang muncul. Ada kebutuhan untuk berbagi perasaan dipertegas oleh KDS berikut ini.

"Sharing, tukar pendapat, sharing perasaan itu penting karena untuk yang baru gabung karena bisa membuka dalam dirinya itu lebih berarti karena mencari informasi tentang HIV-AIDS"

(Koordinator KDS)

\section{Kepemimpinan}

Pemimpin merupakan faktor penting yang menjadi motor penggerak keberlanjutan kelompok. Pemimpin berperan penting dalam mengarahkan, mendampingi dan membangun sistem manajemen. Mengawal keberlanjutan kelompok, dari kelompok informal menjadi kelompok yang formal.

Diakui oleh salah seorang Koordinator KP bahwa pekerjaan rumah selanjutnya adalah membangun sistem manajemen yang harus dimulai dari tingkat pimpinannya. Kapasitas pemimpin yang bertanggungjawab diyakini mampu untuk membangun sistem manajemen kelompok. Meskipun, juga disayangkan bahwa seringkali kendala kepemimpinan seringkali terkendala dengan keterbatasan fisik akibat dari kendala sensor motorik. Akibat kendala tersebut, ODHA yang terkendala sensor motoriknya, seringkali terpaksa diganti oleh orang lain meskipun baik kepemimpinannya sebagaimana ungkapan KP berikut ini.

"PR kami adalah membangun sistem manajemen.

Membangun sistem manajemen ini dimulai dari

kepemimpinan, siapa sih pemimpinnya? Kalau pemimpinnya bertanggung jawab, maka saya yakin sistem manajemen bisa kita bangun. " (Koordinator

KP)

Hal penting yang dapat menjaga keberlanjutan kelompok dalam hal 
kepemimpinan adalah adanya kaderisasi dalam kelompok. Namun, persoalan kaderisasi ini merupakan persoalan yang serius juga. Tidak mudah melakukan kaderisasi dalam hal kepemimpinan dalam operasional kelompok. Terlalu figuritas, atau tidak ada yang mau menjalankan roda organisasi menjadi alasan kelemahan kaderisasi.

"Saya sebenarnya mau ada kaderisasi di dalam menjalankan KP ini. Tapi sayangnya belum ada yang mau menggantikan saya. Semua mau saya yang jadi Ketua. Ada juga masalah konflik antar teman-teman yang perlu saya tengahi." (Koordinator KP)

\section{Kemandirian}

Pembentukan kelompok ini, pada mulanya dimulai secara mandiri dan sukarela. Meskipun untuk mempertahankan independensi kelompok ini kelompok sering terbentur dengan persoalan dana operasional kelompok. Salah satu upaya yang ditempuh adalah dengan cara memiliki usaha yang hasilnya dapat digunakan untuk membiayai keberlanjutan kelompok yang hasilnya dapat digunakan untuk menambah pembiayaan operasianal kelompok sebagaimana diungkapkan oleh seorang KP berikut ini.

"Awalnya, saya dan teman yang lain ingin membentuk sebuah kelompok. Tidak semuanya suka ber NGO. Mereka lebih memilih independent.

Mereka punya usaha dan karya sendiri. Kami saling membantu, dari sisi ide, tenaga, dan juga dana operasional." (Koordinator KP)

Masalah pendanaan yang menggangu operasional lembaga juga dialami oleh KP di wilayah Indonesia Timur. Tingginya biaya operasional untuk menjangkau KDS yang tersebar menjadi kendala. Jarak yang jauh dan biaya operasional yang tinggi tersebut mengganggu kegiatan KDS dalam kunjungan rumah dan kunjungan RS. Masalah tersebut diungkapkan oleh Koordinator KP sebagai berikut ini.

"Yang terjadi di lapangan adalah masalah pendanaan karena dana yang diberikan KP kepada
KDS sangat kecil. Sementara kebutuhan operasional penjangkauan menjadi kendala besar. Kunjungan rumah, kunjungan RS sering terkendala karena tidak ada dukungan operasional yang jangkauannya lebih dari 2 km- 30 km." (Koordinator KP)

Tantangan geografis dan jauhnya jarak ODHA yang harus dijangkau, meskipun menjadi tantangan tersendiri bagi KDS untuk mendukung ODHA, namun tetap diupayakan agar kegiatan tetap dapat berlanjut. Untuk membuat kegiatan tetap dapat berlanjut, KDS berupaya untuk mengatur kecukupan dana yang ada agar kegiatan dapat tetap berjalan, sebagaimana diungkap oleh KDS berikut ini.

"Kita kan terbentur masalah dana, kadang yang datang dalam pertemuan sampai 16 orang, cuma kita atur saja dalam pembuatan transportasinya."

(Koordinator KDS)

Keterbatasan sumberdaya yang dimiliki kelompok, membuat mereka mengandalkan sifat kesukarelaan (voulenteer) pada KDS yang ada. Sifat kesukarelaan ini pada mulanya merupakan potensi yang dimiliki kelompok yang dapat menjamin keberlanjutan kelompok. Namun, koordinator KP dan KDS menyadari bahwa kesukarelaan tidak dapat menjamin keberlanjutan KDS untuk tetap bertahan.

"Kami ini tidak bisa membayar terlalu mahal dengan dana yang terbatas akhirnya kita mengajak orang yang sifatnya voulenteer kita kasih kepercayaan,

kita suruh belajar akhirnya dari situ tanggung jawab nya menyerupai MK (Manajer Kasus), anggarannya pun bukan dari APBD tetapi dari satu funding Kami juga sudah punya kantor sekretariat."

(Koordinator KDS)

\section{Sumberdaya}

Kondisi fisik, terutama untuk penasun yang memiliki kemungkinan untuk relaps menjadi kendala di dalam menjalankan tugasnya dalam kelompok. Bila pengurus KP atau KDS tiba-tiba relaps, maka dapat dipastikan tugas-tugasnya akan terbengkalai dan dapat mempengaruhi teman yang lainnya. 
Keterbatasan ODHA secara kesehatan dan sumber daya menjadi faktor penghambat dalam keberlanjutan kelompok. Tentu saja, pengurus KDS yang pengangguran dan dasar pengetahuannya rendah menjadi beban bagi kelompok untuk program pemberdayaan positif ODHA.

"Tidak semua kebutuhan KDS itu dapat kita jawab, karena dalam beberapa daerah kebutuhan KDS itu cukup besar sekali, tetapi ada juga di beberapa daerah kelompok ini pengurusnya pengangguran, dasar pengetahuannya juga tidak ada."

(Koordinator KP)

permasalahan internal kelompok yang teridentifikasi sebelumnya, seperti motivasi yang rendah, pendidikan dan pengalaman organisasi yang terbatas sebagaimana ungkapannya berikut ini.

"Rekrutmen dilakukan secara profesional, pertama untuk kelompok dampingan anggota kelompok, kedua untuk relawan dan kelompok KDS. Proses rekrutmen relawan dan staf berbeda dan bersifat independent.Kami memiliki tim adhoc khusus untuk rekrutmen SDM sekarang." (Koordinator KP)

\section{Manajemen dan Akuntabilitas Keuangan}

Sebagian besar KP dan KDS mengalami perubahan jenis kelompok, yang semula informal berubah menjadi kelompok formal. Kelompok formal ditandai dengan adanya legalitas akte pendirian, AD/ART, struktur organisasi dan peraturan-peraturan yang berlaku. Kelompok yang semula tidak memiliki struktur organisasi, pembagian peran antar pengurus kemudian harus berubah agar dapat memenuhi persyaratan formal lembaga.

"Karena sebelumnya kita tidak punya

legalitas dan struktur organisasi yang mapan maka

kurang si pemberi dananya, oleh sebab itu

terbenaklah gagasan bahwa teman-teman harus

menjadi penggagas untuk terbentuknya suatu

Yayasan." (Koordinator KDS)

Perubahan jenis kelompok dari informal ke formal memiliki konsekuensi terhadap peningkatan kapasitas sistem manajemen kelompok. Namun, mengubah perilaku pengurus kelompok yang semula kelompok informal menjadi kelompok formal tidaklah mudah. Pengurus yang terbiasa terlambat akhirnya dapat hadir tepat waktu setelah menyepakati kesepakatan bersama.

\section{"Masalah ketepatan waktu mereka hadir tepat waktu dan itu dengan kesepakatan bersama, akhirnya mereka bisa tetap hadir"}

(Koordinator KDS)

Sistem manajemen yang semula tidak baku dan dilakukan semampunya kemudian berubah menjadi manajemen yang memiliki acuan. Pertemuan-pertemuan yang semula berjalan tanpa aturan kemudian harus berubah untuk mematuhi berbagai macam peraturan. Proses perubahan untuk memperkuat sistem manajemen diantaranya dicapai melalui dukungan yang dilakukan oleh KP kepada KDS.

"Kami memotivasi bagaimana KDS menjadi

kuat sebagai sistem manajemen. Setelah mereka kuat secara sistem manajemen tentunya mereka dapat membantu mengelola lebih banyak lagi individu yang akan mereka support dengan informasi dan dukungan."

(Koordinator KP)

Peningkatan sistem manajemen secara otomatis membuat pengurus kelompok harus memenuhi persyaratan akuntabilitas. Ketrampilan dalam pembuatan laporan keuangan dan naratif menjadi syarat mendasar untuk terpenuhinya akuntabilitas kelompok. Kesadaran akan pentingnya akuntabilitas kelompok ini membuat kelompok tidak berani membuat laporan yang asal jadi.

"Kita juga memikirkan akuntabilitasnya. Akuntabilitasnya ini kan sekarang penting, bukan sekedar pertemuan-pertemuan dan laporannya asalasal dibuat." (Koordinator KP)

Untuk memenuhi kebutuhan peningkatan kapasitas pengelolaan kelompok, maka KP dan KDS membutuhkan peningkatan kapasitas yang 
berkelanjutan. KP memfasilitasi KDS untuk mengikuti pelatihan manajemen, pembuatan proposal, pengelolaan keuangan dan organisasi.

"Untuk meningkatkan profesionalisasi lembaga, kami menfasilitasi semacam pelatihan, manajemen, contoh bikin proposal atau mengelola uang atau organisasi yang baik." (Koordinator KP)

\section{Keterlibatan Di Dalam Sistem Penanggulangan HIV/AIDS}

Program peningkatan kapasitas yang semula dilakukan oleh Spiritia kepada KP sekarang juga sudah dilakukan secara lebih luas bekerjasama dengan pihak-pihak terkait. KP juga memfasillitasi KDS untuk ikut serta dalam peningkatan kapasitas di tingkat provinsi atau pun Kota/Kab sebagaimana ungkapan berikut ini.

"Kita berdayakan teman-teman melalui pengurus, mengikut sertakan mereka dalam kegiatan-kegiatan peningkatan kapasitas dan melakukan monitoring ke daerah. Selain itu, kamu juga membantu kesulitan atau persoalan bisa membantu untuk memecahkan nya bahkan menghubungkan dengan pemerintah daerah, dengan KPA kota." (Koordinator KP) Hampir semua KP menyatakan keterlibatannya dalam Sistem Penanggulangan HIV/AIDS di tingkat Provinsi yang dikuatkan posisinya dalam SK Gubernur dan direkrut oleh Dinas Kesehatan.

"Tahun 2006 atau 2007 saya jadi pengurus KPAP.

Dinas Kesehatan juga yang merekrut kita, Odha waktu itu ada saya dan teman saya." (Koordinator $\mathrm{KP})$

Senada dengan pendapat tersebut, keterlibatan KP di KPAP cukup signifikan. Bahkan, secara tegas seorang KP menyatakan bahwa KP yang dipimpinnya merupakan satusatunya LSM yang masuk ke SK Gubernur. Sebagai satu-satunya LSM yang masuk ke dalam SK Gubernur menggambarkan bahwa KP adalah organisasi yang cukup kuat keterlibatannya dalam Pokja-Pokja di tingkat provinsi.
"Cukup aktif kita mba. Dalam SK yang terakhir ini 2009-2013, Kami hanya satu-satu nya LSM yang masuk ke SK Gubernur. Jadi, ini adalah organisasi yang cukup kuat keterlibatannya dalam Pokja-pokja di tingkat provinsi." (Koordinator KP)

Namun, sayangnya belum semua KP merasa menjadi mitra KPAP. Hal ini menunjukkan bahwa dalam realisasi bentuk kerjasama dan kemitraan yang berjalan KP belum merasa sepenuhnya dilibatkan termasuk di dalam proses penyusunan perencanaan, pelaksanaan dan monitoring serta evaluasi program HIV di tingkat Provinsi tergambar dalam ungkapan sebagai berikut.

"Kalau untuk terlibat sebagai mitra dengan KPAP

sampai hari ini belum. Mereka menjanjikan, kami akan dilibatkan sebagai populasi kunci ketika

kunjungan ke daerah. Tapi sampai saat belum dilibatkan." (Koordinator KP)

Pada tingkat Kota/Kab, tidak semua KDS terlibat dalam kepengurusan KPAK. Meskipun KDS merasa telah membangun komunikasi yang baik kepada pihak KPAK, namun KDS belum masuk ke dalam kepengurusan KPAK tingkat Kota/Kab sebagaimana terungkap dalam pernyataan KDS seabagai berikut.

"Kalau komunikasi dengan KPA baik-baik saja, tetapi kalau KDS menjadi anggota KPA belum

pernah, SK juga tidak ada, seharus nya ada SK supaya jelas" (Koordinator KDS)

Peran advokasi adalah gambaran keterlibatan KP dan KDS di dalam sistem penanggulangan HIV/AIDS di tingkat Provinsi dan Kota/Kabupaten. Sebagian besar ODHA mengalami kesulitan berkomunikasi dengan dokter dan petugas kesehatan lainnya. Tingkat kepercayaan diri yang rendah merupakan salah satu faktor penghambatnya.

Salah satu peran penting KP dan KDS adalah menjadi jembatan komunikasi antara ODHA, OHIDHA dan pihak-pihak terkait. Satu hal yang banyak dibantu KP dan KDS adalah menjelaskan tentang cara mengurus Jamkesda 
yang sebagian besar tidak tahu. Namun, sejak sudah mengetahui prosedur yang harus dilakukan, sekarang sebagian besar ODHA sudah mampu mengurusnya sendiri sebagaimana diungkapkan oleh KP sebagai berikut.

"Kami menjalankan peran sebagai jembatan. Misalnya, sabagian besar teman-teman tidak punya Jamkesmas. Kita bisa melibatkan teman-teman dalam mengurus Jaminan Kesehatan Daerah kartu berobat gratis." (Koordinator KP)

\section{Kemampuan Mengakses Anggaran}

Kemampuan mengakses anggaran adalah salah satu ketrampilan dasar yang dilatih oleh Spiritia kepada KP. Spiritia memberikan pelatihan manajemen, kepemimpinan, membuat proposal, laporan keuangan dan publik speaking. Bukan hanya memberikan bekal ketrampilan membuat proposal, tapi juga membantu akses anggaran pada jejaring donor.

"Selain didorong untuk membuat NGO, kami juga dilatih dan didampingi dalam berbagai macam pelatihan seperti manajemen, kepemimpinan, pembuatan proposal, laporan keuangan, dan public speaking. Spiritia ini yang membangun kami mampu melakukan kegiatan-kegiatan itu dan dibantu akses

ke dalam jaringan Spiritia." (Koordinator KP)

APBD Provinsi maupun Kota/Kabupaten adalah salah satu sumber anggaran yang dapat diakses oleh KP dan KDS. Namun, kemampuan untuk memenuhi persyaratan untuk mendapatkan bantuan sosial dari pemerintah daerah ternyata tidaklah cukup.

Salah seorang KP mengungkapkan bahwa kelompoknya belum mengakses APBD karena kesulitan dalam mengakses informasi. Ia merasa pemerintah mempersulitnya untuk memperoleh informasi yang terkait dengan akses APBD. Namun, meskipun mengaku tidak tertarik, ia tetap berusaha untuk mengakses APBD agar dapat terlibat dalam pengambilan keputusan dan mengetahui besaran dana yang dialokasikan.

"Belum mengakses APBD. Tidak pernah, kami kurang tertarik. Makanya, saya bilang tadi kalau boleh jujur saya tidak tertarik kerja dengan pemerintah selama mereka mempersulit saya untuk bagaimana saya memperoleh informasi."(Koordinator KP)

Terkait dengan belum mampunya KP atau KDS mengakses anggaran APBD salah satu persyaratannya adalah terkait dengan persyaratannya yang harus dipenuhi. Bila belum memenuhi persyatan, maka KP atau KDS tidak bisa mengakses anggaran APBD.

Namun, ada pula KP yang mengakui bahwa setelah mendapatkan rangkaian pembekalan dan peningkatan kapasitas dari Spiritia, mereka menindaklanjuti dengan kerjasama di tingkat provinsi, diantaranya Dinas Kesehatan Provinsi. Kerjasama dengan Dinas Kesehatan pun berjalan dengan baik hingga saat ini, termasuk dalam hal akses anggaran.

"kerjasama kami dengan Dinkes berjalan dengan baik sampai sekarang." (Koordinator KP)

\section{Masuk Ke Dalam Sistem Rujukan}

Masuk ke dalam sistem rujukan di Rumah Sakit berarti sebagai kelompok komunitas diakui telah menjadi bagian dari acuan bagi pemberdayaan positif di Rumah Sakit. Melalui upaya yang panjang, pihak Rumah Sakit mengakui bahwa KP dan KDS adalah kelompok komunitas yang menjadi sistem rujukan di RSUD. Artinya, eksistensi KP dan KDS telah mengakui eksistensi dan peran penting KP dan KDS dalam mendampingi ODHA yang baru saja tahu status.

"Ya, KP itu sepertinya menjadi satu-satunya kelompok dukungan sebaya yang menjadi sistem rujukan di RSUD Jadi, kita sudah diakui ekistensi kita sebagai dukungan sebaya di RSUD."

(Koordinator KP)

Proses untuk menjadi rujukan kesehatan ini bukanlah hal yang sederhana. Kerja keras dari KP dan KDS dan bukti bahwa dengan memberikan dukungan kepada ODHA ternyata dapat memberikan perubahan positif yang signifikan. 
" Awalnya, sebagian stakeholder menilai kami adalah lembaga yang mencari persoalan. Tapi kalau sekarang sudah menjadi rujukan kesehatan."

(Koordinator KP)

Dukungan masuknya KDS ke dalam sistem rujukan di rumah sakit diakui oleh pihak Dinas Kesehatan. Dukungan tersebut menunjukkan bahwa memang KDS memiliki peran penting bagi pemberdayaan positif ODHA yang baru tahu statusnya. Masuknya KDS ke dalam sistem jejaring sekaligus mendorong KDS juga masuk ke dalam jaringan. Masuknya KDS ke dalam sistem rujukan juga sekaligus memperkuat tim VCT dan PMTCT di RSUD.

Berjalannya sistem rujukan yang dijalankan KP dan KDS tidak sepenuhnya ditanggapi positif oleh petugas kesehatan. Ada pula petugas kesehatan yang merasa terganggu, karena merasa bahwa KP dan KDS terlalu melampaui kewenangan dalam pendampingan, seperti untuk masalah pengobatan.

"Kami bukannya menjelaskan tentang obat-obatan, tapi hanya saling mengingatkan untuk tidak lupa minum obat dan patuh. Cuma, karena kami punya banyak sumber informasi tentang obat HIV, jadi kesannya tenaga kesehatan yang kurang update daripada kami." (Koordinator KDS)

\section{Pembahasan dan Kesimpulan}

Kelompok sosial adalah kumpulan orang yang memiliki kesadaran bersama akan keanggotaan dan saling berinteraksi. Dua faktor utama yang tampaknya mengarahkan pilihan berkelompok adalah kedekatan dan kesamaan.

Keberlanjutan program secara nasional dapat dilihat dari perkembangan kelembagaan, peningkatan sumber daya manusia, dan peningkatan pendanaan. Sumber daya berupa dana dan sarana prasarana yang dimiliki oleh kelompok atau individu pada tahap awal pembentukan kelompok. Beberapa KP memiliki modal berupa dana dan sarana prasarana yang membuat kelompok dapat berjalan di tahap awal. Namun, untuk keberlanjutannya, kelompok harus dapat mencari sumber daya dan mengelolanya agar kelompok dapat terus berlanjut (Sobirin, 2007).

Pada semua provinsi, KP sudah masuk sebagai anggota KPA provinsi sebagai perwakilan dari LSM Peduli AIDS. Namun tentang keaktifan mereka dalam sistem di KPAN, mulai dari perencanaan hingga monitoring dan evaluasi, ternyata cukup beragam. Di tingkat kota/kabupaten belum semua KDS menjadi anggota KPAK. Hal itu dapat terjadi karena KDS belum dikenal oleh stakeholder.

Analisis faktor keberlanjutan KP dan KDS dalam penanggulangan HIV/AIDS di tingkat provinsi dan kota atau kabupaten dilihat dari dua faktor, yaitu faktor internal dan eksternal. Faktor internal kelompok dilihat dari faktor motivasi berkelompok, kepemimpinan, sumber daya, pengelolaan, dan akuntabilitas. Faktor eksternal kelompok dilihat dari faktor terlibat dalam sistem penanggulangan HIV/AIDS, akses sumber daya dan sistem rujukan (Ruky, 2002)

Dalam faktor kepemimpinan, motivasi ODHA dalam membentuk kelompok agar dapat saling menolong antar sesama, sangat penting untuk keberlanjutan kelompok. Dari faktor sumberdaya ditemukan bahwa keterbatasan dana menjadi masalah yang banyak dihadapi oleh kelompok. Jiwa sukarela untuk menolong sesama dapat membantu keberlanjutan kelompok. Walaupun kapasitas SDM ODHA juga ditemukan menjadi kendala untuk keberlanjutan program, namun sudah dicoba melakukan rekrutmen secara profesional untuk pengelola kelompok. Faktor pengelolaan dan akuntabilitas yang paling menonjol adalah bahwa sudah ada perubahan dalam ketrampilan pengelolaan kelompok sejak awal didirikan hingga sekarang, dan kelompok menyadari pentingnya akuntabilitas pengelolaan dana 
kelompok untuk keberlanjutan program (Tynan, 2006)

Faktor keterlibatan di dalam sistem penanggulangan HIV/AIDS di tingkat provinsi dan kabupaten atau kota menemukan bahwa hampir semua KP masuk sebagai pengurus KPAP yang dikuatkan oleh SK Gubernur, namun peran keterlibatan mereka di dalam proses perencanaan hingga pemantauan dan evaluasi dinilai belum optimal (Spirita, 2001: Spirita, 2002)

\section{Daftar Pustaka}

1. Achmad S. Ruky, "Sukses Sebagai Manajer Profesional Tanpa Gelar MM atau MBA", Gramedia Pustaka Utama, 2002

2. Friedland, J., Rewick, R., \& McColl, M. (1996). Coping \& Social Support as determinants of quality of life in HIV/AIDS. AIDS Care, 8,15-31.

3. Green, Chris. Pemberdayaan Positif, Spiritia, 2007, hal 141.

4. Gregory, Derek; Johnston, Ron; Pratt, Geraldine et al., eds (June 2009). "Quality of Life". Dictionary of Human Geography (5th ed.). Oxford: Wiley-Blackwell. ISBN 978-14051-3287-9.
5. Hadley J. Insurance Coverage, Medical Care Use, and Short-Term ealth changes following an unintentional injury or the onset of a chronic condition. JAMA. 2007;297(10):1073-84.

6. KPAN, Strategi dan Rencana Aksi Nasional Penanggulangan HIV dan AIDS 2010 2014.

7. Mc Dowell, Newell, M. (1987). A guide to rating scales and questionnaires. New York : Oxford University Press.

8. Riessman, F. (1965). "The 'Helper-therapy' principle." Social Work, 10, 27-32

9. Sobirin, Ahmad. Budaya Organisasi, STIM Strategi dan Rencana Aksi Nasional Penanggulangan HIV dan AIDS 2010 2014.

10. Yayasan Spiritia. 2001. Dokumentasi Tentang Masalah Diskriminasi terhadap Orang Dengan HIV/AIDS di Indonesia:Tahap Pertama.

11. Yayasan Spiritia. 2002. Dokumentasi Tentang Masalah Diskriminasi terhadap Orang Dengan HIV/AIDS di Indonesia: Tahap Kedua. 